\title{
The role of nuclear factor kappa $B$ in human labour
}

\author{
Tamsin M Lindström and Phillip R Bennett \\ Parturition Research Group, Institute of Reproductive and Developmental Biology, $3^{\text {rd }}$ Floor IRDB, \\ Hammersmith Campus, Imperial College, Du Cane Road, London W12 ONN, United Kingdom
}

Correspondence should be addressed to T M Lindström; Email: t.lindstrom@imperial.ac.uk

\begin{abstract}
Preterm birth remains the leading cause of perinatal mortality and morbidity, largely as a result of a poor understanding of the precise mechanisms controlling labour onset in humans. Inflammation has long been recognised as a key feature of both preterm and term labour, with an influx of inflammatory cells into the uterus and elevated levels of pro-inflammatory cytokines observed during parturition. Nuclear factor kappa B (NF-кB) is a transcription factor family classically associated with inflammation. Accumulating evidence points to a role for NF- $\mathrm{B}$ in the physiology and pathophysiology of labour. NF- $\mathrm{B}$ activity increases with labour onset and is central to multiple pro-labour pathways. Premature or aberrant activation of NF- $\mathrm{B}$ may thus contribute to preterm labour. The current understanding of NF-кB in the context of human labour is discussed here. Reproduction (2005) 130 569-581
\end{abstract}

\section{Introduction}

Human labour is the culmination of fetal maturation, fetal membrane rupture, placental separation, cervical ripening and dilatation, and coordinated uterine contractions. The precise mechanisms controlling the onset of labour in humans remains one of the fundamental unsolved questions in reproductive biology. Understanding this process is of great importance given that premature delivery complicates up to $10 \%$ of pregnancies and is associated with up to $70 \%$ of neonatal morbidity and mortality. Inflammation is now widely accepted to be a key feature of human labour. Microarray and suppression subtractive hybridization studies have demonstrated the up-regulation of a large panel of pro-inflammatory genes in both fetal membranes (Marvin et al. 2002, Bethin et al. 2003) and myometrium (Chan et al. 2002, Charpigny et al. 2003) with labour onset. Extensive work over the last two decades has implicated cytokines and prostaglandins in the parturition process. Parturition is characterised by an influx of inflammatory cells into the uterus (Young et al. 2002) and increased expression of pro-inflammatory cytokines in both preterm and term labour: elevated levels of interleukin-1 $\beta$ (IL-1 $\beta$ ), IL-6 and tumour necrosis factor- $\alpha$ $(\mathrm{TNF}-\alpha)$ are detected in amniotic fluid (Romero et al. 1992, Opsjln et al. 1993, Romero et al. 1993, Maymon et al. 1999), while IL-1 $\beta$ and IL-6 expression is also increased in amnion (Dudley et al. 1996, Keelan et al. 1999), myometrium and choriodecidua (Keelan et al. 1999, Osman et al. 2003) and cervicovaginal secretions (Steinborn et al. 1996, Tanaka et al. 1998). These pro-inflammatory cytokines are thought to contribute to labour onset by stimulating the production of IL-8 and prostaglandins. Prostaglandins, in turn, induce uterine contractions and act in concert with IL-8 to cause cervical ripening and fetal membrane remodelling (Olson 2003).

Nuclear factor-kappa B (NF- $\mathrm{B})$ is a transcription factor family classically associated with inflammation, which is activated in response to infection and pro-inflammatory cytokines, such as those prevalent during labour. Importantly, many pro-inflammatory and labour-associated genes are regulated by $N F-\kappa B$, and aberrant NF- $\mathrm{B}$ activity underlies a number of inflammation-related disorders. Thus, this transcription factor may play a pivotal role in parturition. NF- $\mathrm{B}$ h has been the focus of intense investigation in recent years. Numerous articles have summarized the considerable progress that has been made in elucidating the complexities of NF-кB function and regulation (Hayden \& Ghosh 2004, Schmitz et al. 2004). This review will briefly outline the regulation of $N F-\kappa B$ and focus on the current understanding of NF- $\mathrm{B}$ activity in the context of human labour.

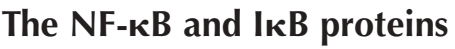

The mammalian NF- $\mathrm{B} /$ Rel family comprises five members: NF-кB1 (p105/p50), NF-кB2 (p100/p52), p65 (RelA), c-rel and RelB (Fig. 1). These proteins share a structurally conserved $\mathrm{N}$-terminal region termed the Rel homology domain (RHD). The RHD mediates dimerization, DNA binding, nuclear localisation and interaction with the 


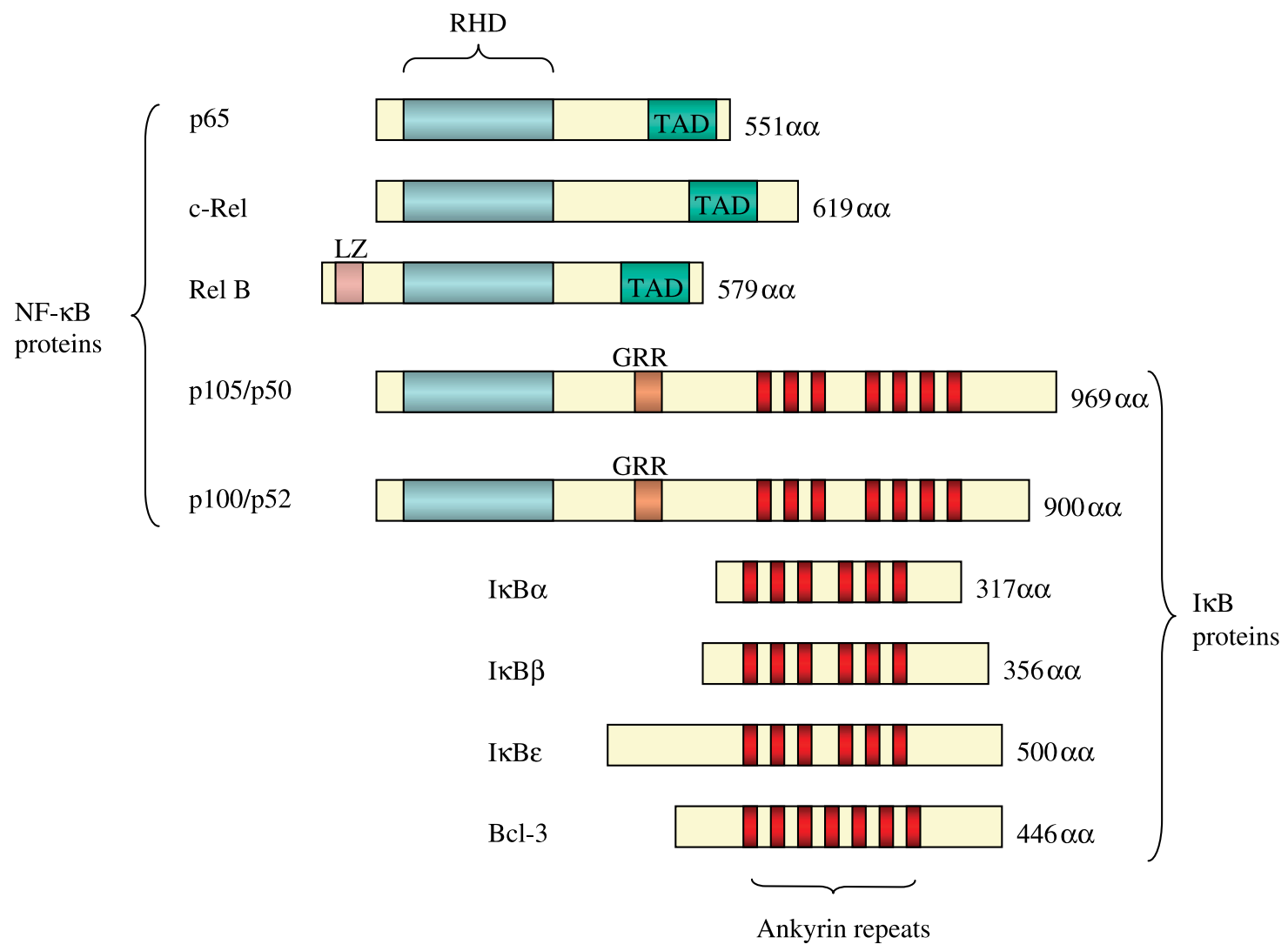

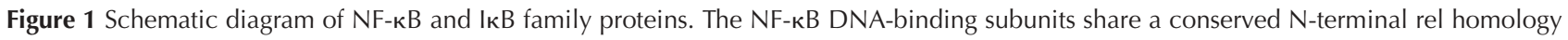
domain (RHD). p65, c-Rel and RelB also have C-terminal transactivation domains (TADs). RelB contains an additional leucine-zipper motif (LZ). The glycine-rich region (GRR) is required for the proteolytic processing of the p105 and p100 precursor proteins, which contain multiple ankyrin repeats, in common with the $І_{\kappa} B$ proteins.

inhibitors of kappa B (ІкB) proteins. In the active form $\mathrm{NF}-\kappa \mathrm{B}$ consists of heterogeneous dimers of various combinations of subunits: each member of the NF-кB family, except for RelB, can form homodimers, as well as heterodimers with one another. RelB forms heterodimers with p100, p52 and p50. The p65, c-rel and RelB proteins contain C-terminal non-homologous transactivation domains (TADs), which are required for transactivation by these proteins. The $\mathrm{p} 50$ and $\mathrm{p} 52$ proteins are generated by proteolytic processing of their precursors, p105 and p100, respectively. The p105 and p100 precursor proteins are constitutively processed through a cotranslational mechanism, but processing of p105 is much more efficient, so that most cells exhibit constitutively high levels of p50, whereas steady-state levels of p52 are low and tightly regulated (Lin et al. 1998, Heusch et al. 1999). The p50 and p52 subunits lack TADs, hence homodimers of these proteins have no intrinsic ability to drive transcription and may bind DNA to repress gene expression in resting cells. The prototypical and most prevalent activated form of NF- $\mathrm{KB}$ is the p50/p65 heterodimer.

In resting cells, NF- $\mathrm{kB}$ is retained in the cytoplasm in an inactive form through association with the $1 \kappa B$ proteins, the most prominent of which are $1 \kappa B \alpha, 1 \kappa B \beta$ and $I_{\kappa} B \varepsilon$. The $I_{\kappa} B s$ are characterized by the presence of multiple ankyrin repeats, which mediate binding to the RHD of NF-KB (ankyrin repeats; protein motifs containing a 33-amino acid long sequence that occur in tandem array and cooperatively fold into structures that mediate protein-protein interactions). The p105 and p100 precursor proteins also contain ankyrin repeats and can function as IкB-like proteins. Crystallographic and mechanistic studies have revealed that $1 \kappa B \alpha$ masks only the nuclear localisation sequence (NLS) of the p65 subunit, leaving the p50 NLS exposed (Huxford et al. 1998). This exposed NLS, coupled with nuclear export sequences (NES) present on $1 \kappa B \alpha$ and p65, results in constant nuclear-cytoplasmic shuttling of the $1 \kappa B \alpha / p 50 / p 65$ complex. Since the export process is more potent than the import process, the steady-state localization of $1 \kappa B \alpha$-bound NF- $\mathrm{kB}$ is in the cytosol (Harhaj \& Sun, 1999, Huang et al. 2000). Simi-

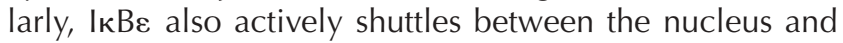
cytoplasm (Lee \& Hannink 2002). In contrast, IкB $\beta$ lacks a

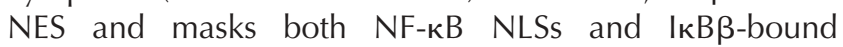
$\mathrm{NF}-\kappa \mathrm{B}$ is consequently sequestered in the cytoplasm of unstimulated cells (Malek et al. 2001). Two unusual IкB proteins are $\mathrm{Bcl}-3$ and $\mathrm{I} B \mathrm{~B} \zeta$. These contain ankyrin repeats but are constitutively nuclear and may act as transactivating transcription factors (Fujita et al. 1993, Yamamoto et al. 2004). 


\section{NF-KB signalling pathways}

Three distinct NF-кB signalling pathways have been delineated to date, all of which rely on sequentially activated kinases, the generation of DNA-binding NF- $\mathrm{kB}$ dimers, and enhancement of the transcriptional activity of NF-кB (Fig. 2).

The so-called canonical pathway is triggered by bacterial lipopolysaccharide (LPS) and pro-inflammatory cytokines, such as IL-1 $\beta$ and TNF $\alpha$. Whilst many of the very early events following receptor engagement are specific for each stimulus (Hayden \& Ghosh, 2004), the signalling converges on the $І \kappa B$ kinase (IKK) complex (Fig. 3). The IKK complex includes the regulatory scaffold protein NF$\kappa B$ essential modulator (NEMO or IKK $\gamma$ ) and the IKK $\alpha$ and IKK $\beta$ kinases. Once activated, IKK phosphorylates $І$ І $B \alpha$ on Ser32 and Ser36 (Traenckner et al. 1995) and this phosphorylation targets $1 \kappa \mathrm{B} \alpha$ for ubiquitination by the $\mathrm{SCF}^{\beta-\operatorname{TrCP}}$ ubiquitin ligase at lysines 21 and 22 $\left(\mathrm{SCF}^{\beta-\operatorname{TrCP}}\right.$; The SCF ligase is composed of Skp1,
Cdc53/Cu11, and a specificity-conferring F-box protein, in this case beta-transducin repeat-containing protein; $\beta \operatorname{TrCP}$ ) (Yaron et al. 1998). Ubiquitinated $\mathrm{I}_{\kappa} \mathrm{B} \alpha$ is subsequently degraded by the $26 \mathrm{~S}$ proteasome, thereby releasing NF- $\mathrm{B}$ dimers from the cytoplasmic $І \kappa \mathrm{B} \alpha / \mathrm{NF}-\kappa \mathrm{B}$ complex, unmasking their NLSs and allowing them to translocate to the nucleus. Canonical NF- $\mathrm{B}$ activation is usually transient as a result of a 'postinduction repression' mechanism. Due to the presence of NF-кB binding sites in the promoter of the $I \kappa B \alpha$ gene, activation of NF- $\kappa B$ leads to the rapid resynthesis of $I_{\kappa} B \alpha$, which accumulates in the nucleus and dissociates NF- $\mathrm{B}$ from DNA-bound complexes (Brown et al. 1993). These newly formed І $\mathrm{B} \alpha / \mathrm{NF}-\kappa \mathrm{B}$ complexes are then exported out to the cytoplasm, in a process mediated by the ІкB $\alpha$ NES (Huang \& Miyamoto, 2001), which restores the cytoplasmic pool of inactive NF-кB. ІкB degradation by the canonical pathway requires the IKK $\beta$ and $\mathrm{NEMO}$ components of the IKK

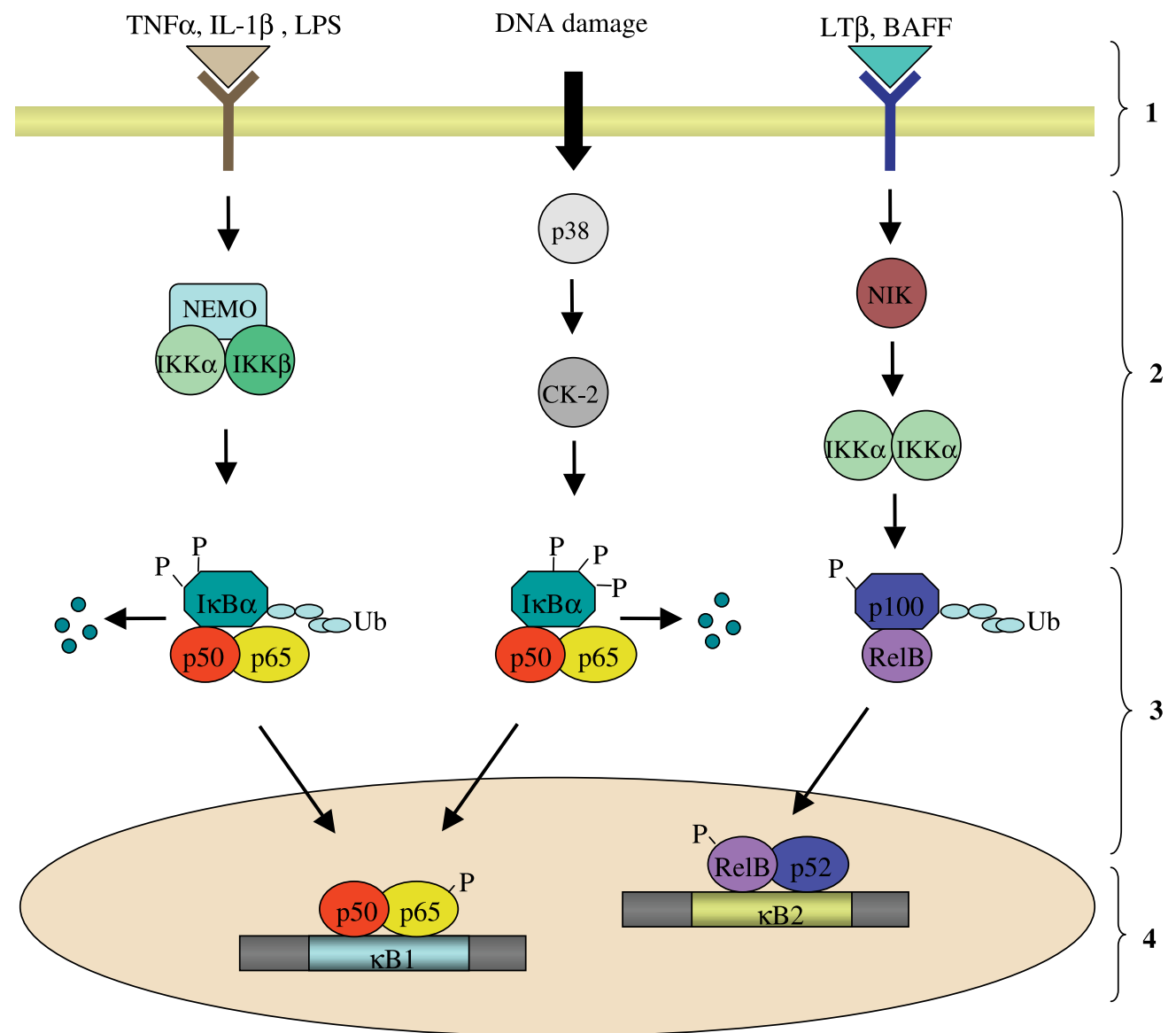

Figure 2 Three distinct NF-кB signalling pathways. The canonical pathway is activated when tumour necrosis factor- $\alpha$ (TNF $\alpha$ ), interleukin-1 $\beta$ (IL-

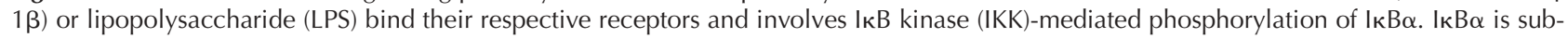
sequently degraded by the proteasome to release p50/p65 dimers. In the atypical pathway, DNA damage results in extensive phosphorylation of I $\mathrm{KB} \alpha$ by $\mathrm{p} 38$-induced casein kinase-2 (CK-2). The noncanonical pathway is triggered by lymphotoxin $\beta$ (LT $\beta$ ) or B-cell activating factor (BAFF) and involves the activation of IKK $\alpha$ by NF-KB inducing kinase (NIK). IKK $\alpha$, in turn, phosphorylates p100, which then undergoes proteasomal processing to generate $\mathrm{p} 52$. RelB/p52 dimers are thus released and translocate to the nucleus to activate genes distinct from those regulated by the canonical pathway. 1. Extracellular stimulus 2. Kinase activation 3. Generation and translocation of active NF-кB dimers 4. DNA-binding and phosphorylation of NF-kB dimers and cofactor recruitment. $\mathrm{P}=$ phosphorylation; $\mathrm{Ub}=$ ubiquitination. 


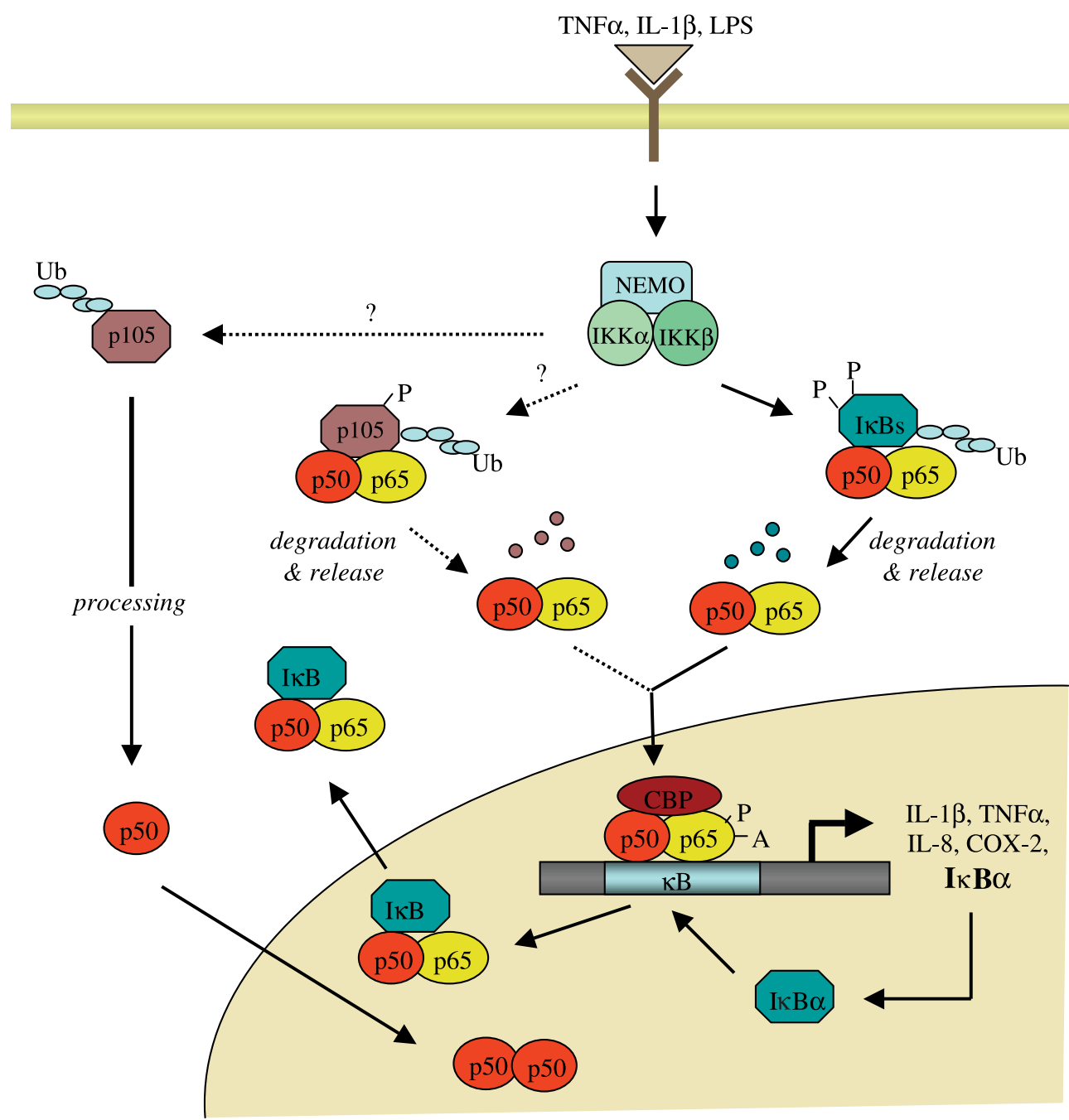

Figure 3 Schematic model of the canonical NF-кB signalling pathway. Stimulation of the cell by tumour necrosis factor- $\alpha$ (TNF $\alpha)$, interleukin-1 $\beta$

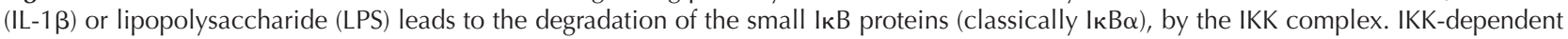
phosphorylation targets $1 \kappa B \alpha$ for ubiquitination $(\mathrm{Ub})$ and degradation by the proteasome. Once $1 \kappa \mathrm{B} \alpha$ is degraded, p65 is phosphorylated $(\mathrm{P})$ and

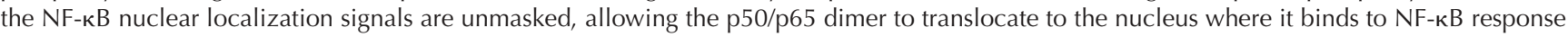
elements $(\kappa \mathrm{B})$ in the promoter of target genes. Induction of p105 degradation may simultaneously occur, thereby releasing further NF-кB dimers, including p50/p65. The p105 precursor may also be processed in response to cytokines to generate additional p50 homodimers, which may take part in NF-кB DNA binding or be displaced from DNA by transactivating dimers. In the nucleus, further phosphorylation and acetylation (A) modifications of NF-кB occur, promoting the recruitment of co-activators, e.g. CREB-binding protein (CBP) to drive transcription. Termination of signalling occurs when newly synthesized ІкB $\alpha$ displaces DNA-bound NF-кB and exports it back to the cytoplasm.

complex (Tanaka et al. 1999, Rudolph et al. 2000) and can involve the degradation of $1 \kappa B \alpha, I \kappa B \beta$ and $1 \kappa B \varepsilon$. The p105 protein may also play a role in the canonical pathway. In addition to the constitutive, cotranslational processing of p105 (Lin et al. 1998), which provides the resting cell with the small amount of p50 required for its basal needs (e.g. low-level transcription or repression of transcription), IKK-dependent phosphorylation and ubiquitination of p105 may occur in response to pro-inflammatory cytokines and LPS (Heissmeyer et al. 1999, Heissmeyer et al. 2001). Such inducible targeting of the p105 precursor can result in two distinct processes, which employ distinct ubiquitin ligases: there may be either complete degradation or limited processing of the protein (Cohen et al. 2004). Presumably processing of p 105 will provide solely p50 subunits whereas degradation may release a variety of NF-kB subunits bound to the p105 ankyrin repeats.

The non-canonical pathway is activated in response to a subset of NF-кB inducers, such as lymphotoxin $\beta$, B-cell activating factor, or the CD40 ligand, although these can also trigger the canonical pathway. In the non-canonical pathway, which is NEMO- and IKK $\beta$-independent (Claudio et al. 2002, Dejardin et al. 2002), IKK $\alpha$ homodimers phosphorylate p100 associated with RelB. This elicits the processing of p100 to p52 and releases transcriptionally 
active RelB/p52 dimers (Dejardin et al. 2002, Xiao et al. 2004). The third pathway is triggered by DNA damage and is considered atypical because it does not involve an initiating receptor ligation event and is independent of the IKK complex. NF-кB activation by UV irradiation, for instance, involves the multiple phosphorylation of $1 \kappa \mathrm{B} \alpha$ on $\mathrm{C}$ terminus residues by the p38-activated casein kinase 2 (Kato et al. 2003). Whilst all the aforementioned signalling pathways have a requirement for proteasomal degradation of one or more $І \kappa B$ proteins, a novel pathway involving proteasome inhibitor-resistant (PIR) degradation has recently been described ( $\mathrm{O}^{\prime}$ Connor et al. 2004). PIR is IKK-dependent and targets $I_{\kappa} \mathrm{B} \alpha$, but not $\mathrm{I}_{\kappa} \mathrm{B} \beta$, resulting in constitutive p50/c-rel activity in B cells.

\section{Multiple levels of NF-кB regulation}

NF- $\kappa$ B is a ubiquitous transcription factor that regulates numerous genes involved in a diverse array of cellular processes. Hence the specificity and temporal control of the NF- $\mathrm{KB}$ response is crucial and multiple levels of control are in place to ensure its tight regulation. As discussed, different stimuli activate distinct kinases, which differentially target $І \kappa B$ degradation. Since the various $І к B$ proteins exhibit distinct preferences for association with particular NF-кB dimers (e.g. ІкB $\alpha$ predominantly binds p50/p65, ІкBe binds p65/c-rel, p100 binds RelB), such selective $І \kappa B$ degradation can determine whether transcriptionally active or repressive NF- $\mathrm{B}$ dimers are released. Furthermore, target genes require specific NF-кB family members for their activation and this varies from gene to gene (Hoffmann et al. 2003). Whilst different stimuli can activate distinct NF-кB dimer combinations, the same stimulus can also elicit distinct waves and subsets of gene activation due to the differential dynamics of $І \kappa B$ degradation and resynthesis coupled with target gene requirements (Hoffmann et al. 2002). Finally, the transcriptional activity of the NF- $\mathrm{B}$ subunits themselves is also regulated by a variety of post-translational modifications, such as phosphorylation, acetylation, ubiquitination and prolyl isomerization (Schmitz et al. 2004). Regulation of NF- $\kappa \mathrm{B}$ signalling is thus complex and celltype differences in NF- $\mathrm{B}$ signalling may depend on which kinases are expressed, which subunits of NF-кB are expressed, in what ratios and on the NF-кB-activating signals to which a given cell responds.

\section{Insights from mice}

A major obstacle in understanding the onset of human labour is the limited ability to extrapolate findings from animal models since there are intrinsic differences between humans and other species in the parturition process, e.g. discordance in the sites and patterns of steroid production. Nevertheless, whilst the role of the corpus luteum and progesterone withdrawal differs between mice and humans, a number of fundamental similarities are apparent. For instance, both mouse and human exhibit an increase in myometrial cell gap junctions and increased uterine sensitivity to oxytocin at term, as well as similar patterns of cytokine expression during infection-related preterm labour. The primary advantage of using the mouse as a model system is the ability to maintain tight experimental control in an in vivo context and to manipulate the mouse genome or proteome in ways that are precluded in human studies due to ethical and practical considerations.

Although genetic disruption of $N f-\kappa b$ genes has not been informative in terms of their contribution to labour onset, studies using mice deficient in p65 (Alcamo et al. 2001), p50 (Sha et al. 1995) or c-rel (Donovan et al. 1999) have confirmed the requirement of these proteins for the mounting of inflammatory sequelae and the response to infection, both of which impinge on the labour process. The establishment of mouse models of parturition is now beginning to yield interesting findings. A crucial role for NF- $\mathrm{B}$ in murine parturition was recently demonstrated in a mouse model of term labour (Condon et al. 2004). Nuclear translocation of the p50 and p65 subunits in the pregnant mouse uterus increased as term approached. Mice injected intra-amniotically with the NF-кB inhibitor peptide SN50 displayed a delay in the onset of labour, whereas control mice injected with the inactive SN50mut peptide delivered at term. Furthermore, surfactant protein-A (SP-A), a protein secreted by the fetal lung that reaches maximal levels at term, was shown to increase p65 nuclear levels in the mouse uterus and induce labour. The authors proposed a model wherein SP-A secreted by the maturing fetal lung acts as a trigger for the onset of parturition at term by inducing the migration of macrophages to the maternal uterus, where they activate $N F-\kappa B$, resulting in the stimulation of uterine contractility. It is not currently clear to what extent these findings can be extrapolated to the human, although the pattern of SP-A synthesis is similar and a 'fetal signal' to parturition is an attractive hypothesis.

Condon et al. (2004) suggest that SP-A signalling to NF-кB during murine parturition may occur via Toll-like receptors (TLRs). TLRs recognize pathogen-associated molecular patterns in specific classes of microbes and are key regulators of both innate and adaptive immune responses. They share considerable homology with the IL-1 receptors and also signal to NF- $\mathrm{B}$ through the canonical pathway. Studies using T/r-4 -/- mutant mice suggest that this TLR is a critical factor in bacterially-induced preterm labour (Wang \& Hirsch 2003). Furthermore, both maternal and fetal polymorphisms of the human TLR-4 gene have been associated with spontaneous preterm labour (Varner \& Esplin 2005). Since NF-кB is known to mediate TLR-4 signalling, these findings imply a role for NF- $\mathrm{B}$ in both spontaneous preterm labour, infection-associated preterm labour and possibly normal labour at term. 


\section{Suppression of NF-кB during pregnancy - $\mathrm{NF}-\mathrm{\kappa B} /$ steroid antagonism}

Suppression of NF-кB activity during pregnancy might be expected if NF- $\kappa$ B does play a role in the onset of labour. McCracken et al. (2004) reported that NF-кB downregulation in $\mathrm{T}$ cells of pregnant women is essential for maintaining the cytokine profile necessary for pregnancy success. Suppression of NF- $\mathrm{B}$ activation in first trimester decidua has also been suggested to contribute to the immunosuppressive mechanisms that prevail during pregnancy (King et al. 2001).

Steroids are present in the circulation at high concentrations throughout gestation and are known to have immunosuppressive effects. The steroid hormone progesterone maintains the uterus in a quiescent state for the majority of pregnancy. In most animal species, a withdrawal of this progesterone effect, manifest as a decline in maternal circulating progesterone levels, precedes the onset of labour at term. Although this does not occur in human pregnancy, the administration of antiprogestins to pregnant women induces labour and enhances sensitivity to oxytocin (Chwalisz 1994). Therefore, in the absence of a demonstrable fall in maternal plasma or tissue progesterone concentrations, it has been postulated that alterations in the functions of the progesterone receptor (PR) may mediate functional or local progesterone withdrawal. In human amnion epithelial cells, a transient transfection system was used to demonstrate mutual antagonism between PR and NF- $\kappa$ B transcriptional activities (Allport et al. 2001). Progesterone itself will also repress IL1- $\beta$ induced expression of NF- $\mathrm{B}$-regulated genes in human amnion (Loudon et al. 2003). This suggests that progesterone may act via its receptor to suppress NF- $\mathrm{B}$ signalling during pregnancy and that the converse, NF-кB mediated repression of $\mathrm{PR}$, may occur in association with labour. A negative direct protein-protein interaction between p65 and PR has been demonstrated in breast cancer cells (Kalkhoven et al. 1996), while, in a preliminary report, Condon et al. (2005) argue that increased p65 expression at term may promote a change in PR isoform predominance, leading to alleviation of the progesterone effect. Progesterone can also bind directly to the oxytocin receptor (OTR) to inhibit its signalling (Grazzini et al. 1998). OTR is a regulator of uterine contractility and contains putative NF- $\mathrm{B}$ binding sites in its gene promoter.

Placental production of glucocorticoids is also markedly increased during pregnancy. The placenta itself is a glucocorticoid-responsive organ and Rosen et al. (1998) demonstrated that NF- $\kappa$ B activity in cytotrophoblasts isolated from human term placenta is chronically suppressed by treatment with the glucocorticoid dexamethasone. Immunohistochemical analysis of cervical tissue from postpartum women compared to that from women at term revealed a decrease in glucocorticoid receptor (GR) levels and a concomitant increase in NF- $\mathrm{B}$ nuclear localisation at parturition (Stjernholm-Vladic et al. 2004). Thus GR-mediated anti-inflammatory mechanisms may also be in place to suppress NF-кB activity and ensure pregnancy maintenance. Such inhibitory mechanisms can occur either through p65/GR protein interactions (Garside et al. 2004) or via the induction of $\mathrm{I} \kappa \mathrm{B} \alpha$ synthesis (Auphan et al. 1995).

\section{NF-кB activity in human labour}

In the study of human labour, there have been no genomic or associative genetic reports directly linking NF- $\mathrm{BB}$ to labour onset. However, activation of NF-кB as a result of alterations in the mechanisms that regulate $\mathrm{NF}-\kappa \mathrm{B}$ may occur with labour and aberrant or premature NF- $\kappa$ B activation could contribute to preterm labour. Research in humans has focused on (i) determining whether the expression or activity of NF- $\mathrm{B}$ proteins increase within the uterus in association with labour, (ii) investigating the activation of NF- $\mathrm{BB}$ by potential triggers of parturition and, (iii) assessing the requirement of pro-labour pathways for NF-кB-mediated transcription.

\section{NF-кB activation in association with labour}

The expression profile and activation of NF-кB family members in myometrial tissue from nonpregnant, term pregnant and spontaneously labouring women was recently reported (Chapman et al. 2004). p65, c-rel, p50, p100 and p105 proteins were detected in tissues from all three groups. Surprisingly, a decrease in p65 protein expression was observed in lower segment myometrium in association with labour, although there was no change in fundal myometrium, which is considered the principal contractile region of the myometrium during labour. This decrease was proposed to occur via the selective recruitment of the proteasome complex to a subset of p65regulated (possibly quiescence-associated) promoters, although this remains to be demonstrated. Nevertheless, NF-кB is generally post-translationally regulated and a shift in subunit composition of the predominant DNAbinding complex was detected, such that binding of potentially repressive p50 homodimers prevailed in pregnant myometrium, whereas p50/p65 heterodimers were dominant in pregnant and labouring myometrium. However, there has recently been a preliminary report (currently in abstract form) of an increase in nuclear and cytosolic p65 expression in fundal uterine segment myometrium in association with human labour (Condon et al. 2005). Increased levels of nuclear NF- $\kappa B$ at parturition have been demonstrated in the cervix (Stjernholm-Vladic et al. 2004).

In amnion, basal and IL-1 $\beta$-induced NF-кB DNA binding activity involves the p50/p65 heterodimer, as well as p65 and p50 homodimers (Lee et al. 2003). Allport et al. (2001) demonstrated that baseline NF-кB DNA binding and transcriptional activity of a NF- $\mathrm{B}$ reporter are 
increased in amnion cells following spontaneous labour relative to amnion cells at term, suggesting that NF-kB plays a role in labour in the amnion. Constitutive NF-kB activity in many cancer cell types is maintained through continuous $\mathrm{I} \mathrm{K} \mathrm{\alpha} \alpha$ turnover, as a result of unrelenting IKK activity (Geleziunas et al. 1998, Carter et al. 2001). However, the increased constitutive NF-кB activity seen in post-labour amnion cells was paralleled by an increase in $I_{\kappa} B \alpha$ expression, suggesting that $I_{\kappa} B \alpha$ is responding to, but not regulating, NF-кB activation (Allport et al. 2001). This apparent paradox is not unprecedented and has been explained by a chaperone-like function of IкB $\beta$. Following stimulus-induced degradation, newly synthesized ІкB $\beta$ accumulates in the nucleus in a hypophosphorylated form, which can bind NF-кB without masking its NLS (Suyang et al. 1996). Hypophosphorylated ІкB $\beta$ may thus maintain persistent $\mathrm{NF}-\mathrm{\kappa B}$ activity by preventing its sequestration by $1 \kappa B \alpha$ and export to the cytoplasm (Thompson et al. 1995, DeLuca et al. 1999). Such an ІкBß-mediated mechanism of sustained NF-кB activity may be responsible for the labour-associated constitutive NF-кB activity observed in the amnion, since ІкВ $\beta$ expression increases with gestational age and labour onset and there is an increase in nuclear localisation of $\iota_{\kappa} B \beta$ in post-labour cells (Lee et al. 2003). However, the phosphorylation status of this nuclear $1 \kappa B \beta$, as well as its possible participation in a ternary complex with NF-кB/DNA, remains to be assessed.

Findings contradictory to the study by Allport et al. (2001) were reported by Yan et al. (2002a) who showed, by immunohistochemical analysis, that p65 is localised principally in the cytoplasm of amnion and chorion at term, regardless of labour status. However, this study did not examine potential changes in posttranslational modifications of p65 (e.g. phosphorylations, acetylations), which are important for its transactivation potential (Schmitz et al. 2004). It is possible that, while a significant increase in nuclear protein levels may not be detectable, labourassociated modifications of pre-existing low-level nuclear p65 could enhance its transcriptional activity. An increase in nuclear localisation of p65 in the decidua was observed with advancing gestation, which was unaffected by labour onset (Yan et al. 2002a).

A number of confounding factors may complicate studies of this nature. Challis and colleagues have proposed that functional regionalization of both chorion and myometrium occurs at term, as a result of progesterone action (Challis et al. 2000). Thus in the cervical, but not the fundal, region of the chorion there is increased production of prostaglandin $E_{2}$ and matrix remodelling. In the myometrium, functional progesterone withdrawal in the fundus induces the expression of contraction-associated proteins (CAPs) and myometrial activation, whereas maintained progesterone signalling in the lower segment myometrium drives the expression of genes that promote relaxation. There may also be inner/outer polarity of the myometrium (Brosens et al. 2002). Discrepancies between studies may therefore reflect the different regions of tissue sampled. Furthermore, Challis et al. (2002) have proposed the existence of four phases of uterine activity during pregnancy and labour: a relatively quiescent phase of pregnancy, an initial 'activation' phase of parturition in which mechanical stretch and uterotrophins lead to upregulation of CAPs and agonist receptors, followed by a 'stimulation' phase in which the uterus responds to uterotonins such as prostaglandins and oxytocin, and a final phase corresponding to postpartum involution. Differences in proximity to labour of the patients classified as not in labour may thus impact on the findings in different studies. The point at which NF-кB is activated in the parturition cascade remains to be elucidated.

\section{Uterine distension}

Stretch is imposed on the myometrium and fetal membranes by the growing fetus throughout pregnancy and more acutely at the time of labour. Studies using unilaterally pregnant rats (Ou et al. 1997) suggest that uterine distension is a major regulator of smooth muscle contractility, which may explain the high rate of preterm labour in conditions such as polyhydramnios and multiple pregnancies. Stretch is also likely to contribute to labour at term: decline in uterine growth relative to fetal growth near the end of pregnancy would increase uterine wall stretch and hence promote myometrial activation (Lye et al. 2001). The OTR plays an important role in uterine contractions during labour (Romero et al. 2000), and OTR mRNA expression is up-regulated by mechanical stretch in pregnant uterine myocytes in vitro (Terzidou et al. 2005). The OTR promoter contains three putative NF-кB binding sites. However, although NF-кB proteins do bind to the OTR promoter and may synergise with the transcription factor CCAAT/enhancer binding protein $\beta$ to induce OTR transcription in myometrium (Terzidou et al. 2003), Johnson and colleagues demonstrated that myometrial NF-кB DNA binding activity is not stimulated by stretch and therefore does not mediate stretch-induced upregulation of OTR expression (Terzidou et al. 2005). In amnion cells, however, stretch does activate NF-кB, which in turn induces expression of cyclo-oxygenase-2 (COX-2), an enzyme important in the production of prostaglandins, see below (Mohan et al. 2005).

\section{Corticotrophin-releasing hormone}

Corticotrophin-releasing hormone $(\mathrm{CRH})$ is a peptide hormone that functions in the hypothalamic-pituitary-adrenal axis to co-ordinate the neuroendocrine response to stress. $\mathrm{CRH}$ is also produced by a number of tissues outside the central nervous system. During pregnancy, the placenta and fetal membranes produce large amounts of $\mathrm{CRH}$, whose levels in maternal and fetal blood and in amniotic fluid peak at term (McLean \& Smith 2001). Placental production of $\mathrm{CRH}$ has been linked with the 
timing of birth and Roger Smith's group have proposed a 'placental clock' hypothesis, in which the rate of increase of maternal plasma $\mathrm{CRH}$ throughout pregnancy influences the timing of labour (McLean et al. 1995).

Thus, in addition to fetal lung SP-A (Condon et al. 2004) and bacterial infection (Romero et al. 2002), CRH is also considered a possible trigger for the onset of labour. Whereas numerous studies demonstrate a link between NF-кB activation and either SP-A (Koptides et al. 1997, Condon et al. 2004) or infection (Lappas et al. 2003), there is little information on a possible link between $\mathrm{CRH}$ and $\mathrm{NF}-\kappa \mathrm{B}$. CRH may exert paracrine or autocrine actions in uterine tissues, in addition to its endocrine effects. Pro-inflammatory local effects of CRH have been demonstrated in a model of aseptic inflammation in rats (Karalis et al. 1991), and NF-кB was recently shown to mediate the pro-inflammatory effects of $\mathrm{CRH}$ in mouse thymocytes (Zhao \& Karalis, 2002). The identification of $\mathrm{CRH}$ and its receptors in myometrium (Clifton et al. 1998, Stevens et al. 1998) suggested that CRH may have a direct effect on this tissue. In a study using myometrial explants, $\mathrm{CRH}$ was unable to stimulate pro-inflammatory cytokine production (Sehringer et al. 2000). However, only lower segment myometrium was examined and $\mathrm{CRH}$ is thought to promote relaxation in the lower segment but stimulate myometrial activity in the fundus (Stevens et al. 1998). $\mathrm{CRH}$ is also expressed in fetal membranes, where it may stimulate prostaglandin production (Jones \& Challis, 1989). NF-кB is an important regulator of prostaglandin production - as discussed below - but a potential link between $\mathrm{CRH}$ and NF-KB activation in fetal membranes has not been addressed.

\section{$N F-\kappa B$ is activated by and regulates pro-inflammatory cytokines}

The importance of pro-inflammatory cytokines in parturition has long been appreciated. A polymorphism in the $T N F-\alpha$ promoter that increases $T N F-\alpha$ gene transcription is associated with preterm birth in black women, whilst an IL-6 gene promoter polymorphism that results in reduced IL-6 production is associated with a decreased risk of preterm birth in Caucasian women (Varner \& Esplin 2005). Concentrations of IL- $1 \beta$, IL-8, IL- 6 and TNF- $\alpha$ are elevated in amniotic fluid and uterine tissues in association with preterm and term labour (Keelan et al. 2003) and mediate infection-induced preterm labour (Romero et al. 2002). Furthermore, systemic administration of IL-1 $\beta$ can induce preterm parturition in pregnant mice (Romero et al. 1991). The high levels of pro-inflammatory cytokines detected in uterine tissues may derive, in part, from infiltrating leukocytes (Young et al. 2002, Osman et al. 2003), but decidual, myometrial, amnion and placental cells can themselves all produce pro-inflammatory cytokines. $\mathrm{NF}-\mathrm{KB}$ is highly inducible by pro-inflammatory stimuli. LPS (Lappas et al. 2002), IL-1 $\beta$ (Belt et al. 1999) and TNF$\alpha$ (Kniss et al. 2001) have all been shown to stimulate
NF-кB activity in uterine tissues. In addition, many genes encoding pro-inflammatory cytokines, such as TNF- $\alpha$, IL-1 $\beta$, IL-8 and IL-6, contain NF-kB recognition elements within their promoters and NF-kB is known to promote the formation of cytokines in many cell types. Cytokineinduced NF-кB can therefore precipitate a positive feedforward loop resulting in amplification of cytokine production and further NF- $\mathrm{kB}$ activation.

Uterine NF-kB expression and activity is reduced in IL-1 $\beta$-deficient pregnant mice compared to pregnant wildtype mice. This is associated with a decrease in cytokine production in response to LPS (Reznikov et al. 2000), indicating an important role for NF- $\mathrm{kB}$ in the inflammatory response in uterine tissues. Repression of NF-кB DNAbinding by the anti-inflammatory agent sulfasalazine (SASP) or the anti-oxidant $\mathrm{N}$-acetyl-cysteine (NAC) inhibits the release of IL-6, IL-8 and TNF- $\alpha$ from LPS-treated placental, choriodecidual and amnion explants (Lappas et al. 2002, Lappas et al. 2003). Soloff et al. (2004) recently reported the in situ binding of the p65 NF-кB subunit to the endogenous $I L-8$ promoter in IL- $1 \beta$-stimulated myometrial cells. Reporter studies in amnion and cervical cells demonstrated that the NF- $\mathrm{kB}$ response element is required for transcription of the $I L-8$ gene in these cells (Elliott et al. 2001).

\section{$N F-\kappa B$ is required for prostaglandin synthesis}

Prostaglandins (PGs) are pivotal to the parturition process, mediating cervical ripening and dilatation and stimulating myometrial contractions (Olson 2003). An increase in PG output precedes the onset of clinical labour (Romero et al. 1996, Brown et al. 1998) and, importantly, drugs that inhibit PG production have been used clinically to attenuate the progression of labour (Besinger et al. 1991), whilst the administration of exogenous PGs induces labour and delivery (Ray \& Garite 1992). The rate-limiting and committing step of PG synthesis is catalysed by the cyclooxygenase (COX) enzymes. The COX enzymes exist as two main isoforms, the constitutively expressed COX-1 and the inducible COX-2 isozyme (a third isoform, COX-3 has recently been described; Berenbaum 2004). Studies in Cox-1 -/- knockout mice show that maternal Cox-1 is necessary and sufficient for murine labour at term (Gross et al. 1998). Cox-2 knockout mice exhibit impaired ovulation and blastocyst implantation, which limits the information that can be gained about the role of COX-2 in murine parturition (Lim et al. 1997). However, Gross et al. (2000) demonstrated that COX-2 but not COX-1 is induced during LPS-mediated preterm labour, and that administration of a COX-2 selective inhibitor was able to prevent preterm delivery. It has been proposed that COX1-derived prostaglandins are responsible for the induction of luteolysis, while COX-2 may be important in the final pathway of parturition (Tsuboi et al. 2000).

In human labour, which does not involve PG-mediated luteolysis, there is substantial evidence for the importance 
of the inducible COX-2. Amnion is a major source of PGs and displays a marked increase in synthesis of $\mathrm{PGE}_{2}$ with labour onset (Bennett et al. 1993). This is associated with the selective induction of the COX-2 gene (Slater et al. 1995). Similarly, chorio-decidual cells exhibit labourassociated upregulation of COX-2, but not COX-1, expression (Slater et al. 1998). Furthermore, COX-2-selective inhibitors may delay premature delivery in women (Mitchell \& Olson 2004).

COX-2 expression in uterine tissues is transcriptionally induced by pro-inflammatory cytokines, such as IL-1 $\beta$ and TNF $\alpha$ (Belt et al. 1999, Kniss et al. 2001). The promoter region of the human COX-2 gene contains two NF-KB response elements and site-directed mutation of either of these elements represses the activity of a COX-2 promoter reporter construct in amnion epithelial cells (Allport et al. 2001). Blocking the nuclear translocation of NF-кB with the SN50 inhibitor peptide results in inhibition of IL-1 $\beta$ induced COX-2 protein synthesis in amnion mesenchymal cells (Yan et al. 2002b). NF-kB is also required for TNF $\alpha$ induced COX-2 expression in trophoblast cells (Kniss et al. 2001). Conversely, Lappas et al. (2004) reported that inhibition of NF-kB DNA binding by SASP did not affect COX-2 expression in LPS-stimulated amnion, placenta or choriodecidua. However, SASP is not a specific NF-кB inhibitor and the authors suggest that SASP could potentially extend the half-life of COX-2. NF-кB inhibition by SASP does, however, repress secretory type II phospholipase $A_{2}$ (an enzyme upstream of COX-2 in the PG biosynthetic pathway) in gestational tissues (Lappas et al. 2004), as does NF-kB inhibition by NAC (Lappas et al. 2003). The in situ binding of the p65 NF-кB subunit to the COX-2 promoter has been demonstrated in IL-1 $\beta$ stimulated myometrial cells by chromatin immunoprecipitation (Soloff et al. 2004). Treatment of myometrial cells with proteasome inhibitors, a COX-2-derived PG metabolite, or a more selective IKK $\beta$ inhibitor, all of which block NF-кB activity, inhibits IL-1 $\beta$-induced COX-2 expression and PG synthesis (Belt et al. 1999, Lindstrom \& Bennett 2005).

\section{$N F-\kappa B$ regulates matrix metalloproteinase expression}

Extensive remodelling of the extracellular matrix (ECM) occurs in several processes during parturition, including fetal membrane rupture (Bryant-Greenwood \& Yamamoto 1995), cervical ripening (Kelly 2002) and placental detachment from the decidua (Tsatas et al. 1999). Fetal membranes consist of amnion and chorion layers connected by ECM, which forms the structural framework of the amnion-chorion. ECM collagens provide the main tensile strength of the fetal membranes. As gestation progresses, programmed collagenolysis takes place, which is mediated by matrix metalloproteinase (MMP) enzymes. A decrease in the collagen content of the membranes and activation of MMPs occurs during labour (Hampson et al. 1997, Goldman et al. 2003), and inappropriate or premature MMP expression and activity is proposed to contribute to the pathological preterm premature rupture of membranes (PPROM) (Vadillo-Ortega \& Estrada-Gutierrez 2005). ECM collagen degradation during cervical ripening occurs in order to allow the cervix to become soft and distensible, thereby accommodating the passage of the fetus during labour. Increases in MMP activity parallel the increase in cervical dilatation (Winkler et al. 1999) and, as with PPROM, premature cervical ripening is a feature of preterm labour (Schmitz 2004).

The onset of labour is associated with an influx of inflammatory cells into the membranes, decidua and cervix (Osman et al. 2003), and MMPs found within the uterus may derive from these infiltrating leukocytes (Vadillo-Ortega \& Estrada-Gutierrez 2005). The chemokine IL-8 is largely responsible for the influx of leukocytes into uterine tissues, where it induces their degranulation and release of MMPs (Osmers et al. 1995). MMPs are also produced by the cervix itself (Stygar et al. 2002), as well as the placenta and fetal membranes (Xu et al. 2002). The production of MMP-9 (Yoo et al. 2002), MMP-1 and MMP-3 (Chase et al. 2002), and MMP-2 (Yoshida et al. 2001) by inflammatory cells requires the activation of NF-кB. Lappas et al (Lappas et al. 2003) have shown that inhibition of NF-кB DNA binding by NAC results in the repression of LPS-stimulated MMP-9 activity in amnion and choriodecidual explants.

\section{NF-кB - a therapeutic target in preterm labour?}

Preterm labour constitutes a syndrome, in that it is the outcome of multiple aetiologies. However, uterine inflammation may represent a final common pathway, mediating labour onset resulting from bacterial infections (Romero et al. 2002), SP-A secretion from the fetal lung (Condon et al. 2004), mechanical stretch (Mohan et al. 2005), or genetic predisposition (Varner \& Esplin 2005). $\mathrm{NF}-\mathrm{\kappa B}$ has long been recognised as a key player in the inflammatory response and work over the last six years has revealed a role for NF- $\mathrm{B} B$ in labour-associated inflammation: NF- $\mathrm{KB}$ is activated by stimuli that induce labour and in turn regulates the expression of molecules involved in the parturition process. Aside from inflammation, a decline in responsiveness to progesterone is also crucial to labour onset in the human, and NF-кB may antagonise PR to bring about a 'functional' progesterone withdrawal. $\mathrm{NF}-\kappa \mathrm{B}$ is thus central to multiple pathways involved in the onset of labour (Fig. 4) and as such constitutes a potential therapeutic target in the management of preterm labour. Treatment directed against NF-кB has the potential to be more effective than current treatments, which do not cast a sufficiently wide therapeutic net and may also have the added advantage of preventing detrimental effects to the fetus that may result from infection/inflammation (Cornette 2004). However, because of its widespread physiological role, the identification of labour-specific NF-кB signalling 


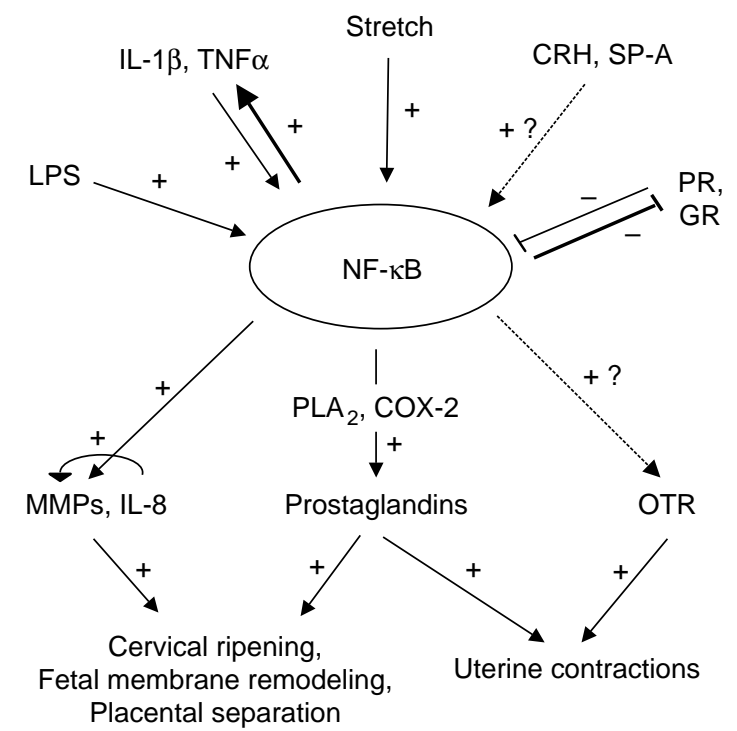

Figure $4 \mathrm{NF}-\mathrm{kB}$ is central to labour-associated pathways. LPS, lipopolysaccharide; IL-1 $\beta$, interleukin-1 $\beta$; TNF $\alpha$, tumour necrosis factor- $\alpha$; $\mathrm{CRH}$, corticotrophin releasing hormone; SP-A, surfactant protein-A; $\mathrm{PR}$, progesterone receptor; GR, glucocorticoid receptor; $\mathrm{PLA}_{2}$, phospholipase $\mathrm{A}_{2}$; COX-2, cyclo-oxygenase-2; MMPs, matrix metalloproteinases; IL-8, interleukin-8; OTR, oxytocin receptor.

components and selective targeting of the NF-кB pathway will be crucial in minimising the systemic toxicity of potential new therapies for preterm labour. The effectiveness of such a strategy may, in part, depend on how early in the parturition process NF- $\mathrm{kB}$ is activated and on the development of improved diagnostic indicators of preterm labour, so that intervention can arrive before a branching cascade has taken hold.

\section{Acknowledgements}

Tamsin Lindström has been funded by Wellbeing and Tommy's Campaign. The authors declare that there is no conflict of interest that would prejudice the impartiality of this scientific work.

\section{References}

Alcamo E, Mizgerd JP, Horwitz BH, Bronson R, Beg AA, Scott M, Doerschuk CM, Hynes RO \& Baltimore D 2001 Targeted mutation of TNF receptor I rescues the RelA-deficient mouse and reveals a critical role for NF-kappa B in leukocyte recruitment. Journal of Immunology 167 1592-1600.

Allport VC, Pieber D, Slater DM, Newton R, White JO \& Bennett PR 2001 Human labour is associated with nuclear factor-kappaB activity which mediates cyclo-oxygenase-2 expression and is involved with the 'functional progesterone withdrawal'. Molecular Human Reproduction 7 581-586.

Auphan N, DiDonato JA, Rosette C, Helmberg A \& Karin M 1995 Immunosuppression by glucocorticoids: inhibition of NF-kappa B activity through induction of I kappa B synthesis. Science $\mathbf{2 7 0}$ 286-290.

Belt AR, Baldassare JJ, Molnar M, Romero R \& Hertelendy F 1999 The nuclear transcription factor NF-kappaB mediates interleukin1 beta-induced expression of cyclooxygenase- 2 in human myometrial cells. American Journal of Obstetrics and Gynecology $181359-366$.

Bennett PR, Slater D, Sullivan M, Elder MG \& Moore GE 1993 Changes in amniotic arachidonic acid metabolism associated with increased cyclo-oxygenase gene expression. British Journal of Obstetrics and Gynaecology 100 1037-1042.

Berenbaum F 2004 COX-3: fact or fancy? Joint Bone Spine 71 451-453.

Besinger RE, Niebyl JR, Keyes WG \& Johnson TR 1991 Randomized comparative trial of indomethacin and ritodrine for the long-term treatment of preterm labor. American Journal of Obstetrics and Gynecology 164 981-986; discussion 986-988.

Bethin KE, Nagai Y, Sladek R, Asada M, Sadovsky Y, Hudson TJ \& Muglia LJ 2003 Microarray analysis of uterine gene expression in mouse and human pregnancy. Molecular Endocrinology 17 1454-1469.

Brosens JJ, Pijnenborg R \& Brosens IA 2002 The myometrial junctional zone spiral arteries in normal and abnormal pregnancies: a review of the literature. American Journal of Obstetrics and Gynecology 187 1416-1423.

Brown K, Park S, Kanno T, Franzoso G \& Siebenlist U 1993 Mutual regulation of the transcriptional activator NF-kappa B and its inhibitor, I kappa B-alpha. PNAS 90 2532-2536.

Brown NL, Alvi SA, Elder MG, Bennett PR \& Sullivan MH 1998 A spontaneous induction of fetal membrane prostaglandin production precedes clinical labour. Journal of Endocrinology 157 R1-R6.

Bryant-Greenwood GD \& Yamamoto SY 1995 Control of peripartal collagenolysis in the human chorion-decidua. American Journal of Obstetrics and Gynecology 172 63-70.

Carter RS, Geyer BC, Xie M, Acevedo-Suarez CA \& Ballard DW 2001 Persistent activation of NF-kappa B by the tax transforming protein involves chronic phosphorylation of IkappaB kinase subunits IKKbeta and IKKgamma. Journal of Biological Chemistry 276 $24445-24448$.

Challis JRG, Matthews SG, Gibb W \& Lye SJ 2000 Endocrine and paracrine regulation of birth at term and preterm. Endocrine Reviews 21 514-550.

Challis JRG, Sloboda DM, Alfaidy N, Lye SJ, Gibb W, Patel FA, Whittle WL \& Newnham JP 2002 Prostaglandins and mechanisms of preterm birth. Reproduction 124 1-17.

Chan EC, Fraser S, Yin S, Yeo G, Kwek K, Fairclough RJ \& Smith R 2002 Human myometrial genes are differentially expressed in labor: a suppression subtractive hybridization study. Journal of Clinical Endocrinology and Metabolism 87 2435-2441.

Chapman NR, Europe-Finner GN \& Robson SC 2004 Expression and deoxyribonucleic acid-binding activity of the nuclear factor kappaB family in the human myometrium during pregnancy and labor. Journal of Clinical Endocrinology and Metabolism 89 5683-5693.

Charpigny G, Leroy MJ, Breuiller-Fouche M, Tanfin Z, MhaoutyKodja S, Robin P, Leiber D, Cohen-Tannoudji J, Cabrol D, Barberis C et al. 2003 A functional genomic study to identify differential gene expression in the preterm and term human myometrium. Biology of Reproduction 68 2289-2296.

Chase AJ, Bond M, Crook MF \& Newby AC 2002 Role of nuclear factor-kappa B activation in metalloproteinase-1, -3, and -9 secretion by human macrophages in vitro and rabbit foam cells produced in vivo. Arteriosclerosis Thrombosis and Vascular Biology $22765-771$.

Chwalisz K 1994 The use of progesterone antagonists for cervical ripening and as an adjunct to labour and delivery. Human Reproduction 9 Supplement 1 131-161.

Claudio E, Brown K, Park S, Wang H \& Siebenlist U 2002 BAFFinduced NEMO-independent processing of NF-kappa B2 in maturing B cells. Nature Immunology 3 958-965.

Clifton VL, Telfer JF, Thompson AJ, Cameron IT, Teoh TG, Lye SJ \& Challis JR 1998 Corticotropin-releasing hormone and proopiomelanocortin-derived peptides are present in human myometrium. Journal of Clinical Endocrinology and Metabolism 83 $3716-3721$. 
Cohen S, Achbert-Weiner H \& Ciechanover A 2004 Dual effects of IkappaB kinase beta-mediated phosphorylation on p105 Fate: SCF(beta-TrCP)-dependent degradation and SCF(beta-TrCP)-independent processing. Molecular and Cellular Biology 24 475-486.

Condon JC, Jeyasuria P, Faust JM \& Mendelson CR 2004 Surfactant protein secreted by the maturing mouse fetal lung acts as a hormone that signals the initiation of parturition. PNAS 101 4978-4983.

Condon JC, Hardy DB \& Mendelson CR 2005 Temporal and spatial activation of NF-kB in human fundal myometrium and in mouse uterus near term causes upregulated expression of the inhibitory progesterone receptor (PR)-C isoform and a withdrawal of PR function leading to labor. ENDO 2005 Program \& Abstracts The Endocrine Society's 87th Annual Meeting OR13-14, p. 90.

Cornette L 2004 Fetal and neonatal inflammatory response and adverse outcome. Seminars in Fetal \& Neonatal Medicine 9 459-470.

Dejardin E, Droin NM, Delhase M, Haas E, Cao Y, Makris C, Li ZW, Karin M, Ware CF \& Green DR 2002 The lymphotoxin-beta receptor induces different patterns of gene expression via two NF-kappaB pathways. Immunity 17 525-535.

DeLuca C, Petropoulos L, Zmeureanu D \& Hiscott J 1999 Nuclear IkappaBbeta maintains persistent NF-kappaB activation in HIV-1infected myeloid cells. Journal of Biological Chemistry $27 \mathbf{4}$ 13010-13016.

Donovan CE, Mark DA, He HZ, Liou HC, Kobzik L, Wang Y, De Sanctis GT, Perkins DL \& Finn PW 1999 NF-kappa B/Rel transcription factors: c-Rel promotes airway hyperresponsiveness and allergic pulmonary inflammation. Journal of Immunology $\mathbf{1 6 3}$ 6827-6833.

Dudley DJ, Collmer D, Mitchell MD \& Trautman MS 1996 Inflammatory cytokine mRNA in human gestational tissues: implications for term and preterm labor. Journal of the Society for Gynecologic Investigation 3 328-335.

Elliott CL, Allport VC, Loudon JA, Wu GD \& Bennett PR 2001 Nuclear factor-kappa B is essential for up-regulation of interleukin8 expression in human amnion and cervical epithelial cells. Molecular Human Reproduction 7 787-790.

Fujita T, Nolan GP, Liou HC, Scott ML \& Baltimore D 1993 The candidate proto-oncogene bcl-3 encodes a transcriptional coactivator that activates through NF-kappa B p50 homodimers. Genes \& Development 7 1354-1363.

Garside H, Stevens A, Farrow S, Normand C, Houle B, Berry A Maschera B \& Ray D 2004 Glucocorticoid ligands specify different interactions with NF-kappaB by allosteric effects on the glucocorticoid receptor DNA binding domain. Journal of Biological Chemistry 279 50050-50059.

Geleziunas R, Ferrell S, Lin X, Mu Y, Cunningham ET Jr, Grant M, Connelly MA, Hambor JE, Marcu KB \& Greene WC 1998 Human T-cell leukemia virus type 1 Tax induction of NF-kappaB involves activation of the IkappaB kinase alpha (IKKalpha) and IKKbeta cellular kinases. Molecular and Cellular Biology 18 5157-5165.

Goldman S, Weiss A, Eyali V \& Shalev E 2003 Differential activity of the gelatinases (matrix metalloproteinases 2 and 9) in the fetal membranes and decidua, associated with labour. Molecular Human Reproduction 9 367-373.

Grazzini E, Guillon G, Mouillac B \& Zingg HH 1998 Inhibition of oxytocin receptor function by direct binding of progesterone. Nature 392 509-512.

Gross GA, Imamura T, Luedke C, Vogt SK, Olson LM, Nelson DM Sadovsky Y \& Muglia LJ 1998 Opposing actions of prostaglandins and oxytocin determine the onset of murine labor. PNAS 95 11875-11879.

Gross G, Imamura T, Vogt SK, Wozniak DF, Nelson DM, Sadovsky Y \& Muglia LJ 2000 Inhibition of cyclooxygenase-2 prevents inflammation-mediated preterm labor in the mouse. American Journal of Physiology: Regulatory, Integrative and Comparative Physiology 278 R1415-R1423.
Hampson V, Liu D, Billett E \& Kirk S 1997 Amniotic membrane collagen content and type distribution in women with preterm premature rupture of the membranes in pregnancy. British Journal of Obstetrics and Gynaecology 104 1087-1091.

Harhaj EW \& Sun SC 1999 Regulation of RelA subcellular localization by a putative nuclear export signal and p50. Molecular and Cellular Biology 19 7088-7095.

Hayden MS \& Ghosh S 2004 Signaling to NF-kappaB. Genes \& Development 18 2195-2224.

Heissmeyer V, Krappmann D, Wulczyn FG \& Scheidereit C 1999 NF-kappaB p105 is a target of IkappaB kinases and controls signal induction of Bcl-3-p50 complexes. EMBO J 18 4766-4778.

Heissmeyer V, Krappmann D, Hatada EN \& Scheidereit C 2001 Shared pathways of IkappaB kinase-induced SCF(betaTrCP)-mediated ubiquitination and degradation for the NF-kappaB precursor p105 and IkappaBalpha. Molecular and Cellular Biology 21 1024-1035.

Heusch M, Lin L, Geleziunas R \& Greene WC 1999 The generation of nfkb2 p52: mechanism and efficiency. Oncogene $\mathbf{1 8}$ $6201-6208$.

Hoffmann A, Levchenko A, Scott ML \& Baltimore D 2002 The IkappaB-NF-kappaB signaling module: temporal control and selective gene activation. Science 298 1241-1245.

Hoffmann A, Leung TH \& Baltimore D 2003 Genetic analysis of NFkappaB/Rel transcription factors defines functional specificities. EMBO J 22 5530-5539.

Huang TT, Kudo N, Yoshida M \& Miyamoto S 2000 A nuclear export signal in the $\mathrm{N}$-terminal regulatory domain of IkappaBalpha controls cytoplasmic localization of inactive NF-kappaB/lkappaBalpha complexes. PNAS 97 1014-1019.

Huang TT \& Miyamoto S 2001 Postrepression activation of NF-kappaB requires the amino-terminal nuclear export signal specific to IkappaBalpha. Molecular and Cellular Biology 21 $4737-4747$

Huxford T, Huang DB, Malek S \& Ghosh G 1998 The crystal structure of the IkappaBalpha/NF-kappaB complex reveals mechanisms of NF-kappaB inactivation. Cell 95 759-770.

Jones SA \& Challis JR 1989 Local stimulation of prostaglandin production by corticotropin-releasing hormone in human fetal membranes and placenta. Biochemical and Biophysical Research Communications 159 192-199.

Kalkhoven E, Wissink S, van der Saag PT \& van der Burg B 1996 Negative interaction between the RelA(p65) subunit of NF-kappaB and the progesterone receptor. Journal of Biological Chemistry $\mathbf{2 7 1}$ $6217-6224$

Karalis K, Sano H, Redwine J, Listwak S, Wilder RL \& Chrousos GP 1991 Autocrine or paracrine inflammatory actions of corticotropinreleasing hormone in vivo. Science 254 421-423.

Kato T Jr, Delhase M, Hoffmann A \& Karin M 2003 CK2 Is a C-Terminal IkappaB Kinase Responsible for NF-kappaB Activation during the UV Response. Molecular Cell 12 829-839.

Keelan JA, Marvin KW, Sato TA, Coleman M, McCowan LM \& Mitchell MD 1999 Cytokine abundance in placental tissues: evidence of inflammatory activation in gestational membranes with term and preterm parturition. American Journal of Obstetrics and Gynecology 181 1530-1536.

Keelan JA, Blumenstein M, Helliwell RJ, Sato TA, Marvin KW \& Mitchell MD 2003 Cytokines, prostaglandins and parturition-a review. Placenta 24 Supplement A S33-S46.

Kelly RW 2002 Inflammatory mediators and cervical ripening. Journal of Reproductive Immunology 57 217-224.

King AE, Critchley HO \& Kelly RW 2001 The NF-kappaB pathway in human endometrium and first trimester decidua. Molecular Human Reproduction 7 175-183.

Kniss DA, Rovin B, Fertel RH \& Zimmerman PD 2001 Blockade NFkappaB activation prohibits TNF-alpha-induced cyclooxygenase-2 gene expression in ED27 trophoblast-like cells. Placenta 22 $80-89$. 
Koptides M, Umstead TM, Floros J \& Phelps DS 1997 Surfactant protein A activates NF-kappa B in the THP-1 monocytic cell line. American Journal of Physiology 273 L382-L388.

Lappas M, Permezel M, Georgiou HM \& Rice GE 2002 Nuclear factor kappa B regulation of proinflammatory cytokines in human gestational tissues in vitro. Biology of Reproduction 67 668-673.

Lappas M, Permezel M \& Rice GE 2003 N-Acetyl-cysteine inhibits phospholipid metabolism, proinflammatory cytokine release, protease activity, and nuclear factor-kappaB deoxyribonucleic acidbinding activity in human fetal membranes in vitro. Journal of Clinical Endocrinology and Metabolism 88 1723-1729.

Lappas M, Permezel M, Georgiou HM \& Rice GE 2004 Regulation of phospholipase isozymes by nuclear factor-kappaB in human gestational tissues in vitro. Journal of Clinical Endocrinology and Metabolism $892365-2372$.

Lee SH \& Hannink M 2002 Characterization of the nuclear import and export functions of Ikappa B(epsilon). Journal of Biological Chemistry $27723358-23366$.

Lee Y, Allport V, Sykes A, Lindstrom T, Slater D \& Bennett P 2003 The effects of labour and of interleukin 1 beta upon the expression of nuclear factor kappa B related proteins in human amnion. Molecular Human Reproduction 9 213-218.

Lim H, Paria BC, Das SK, Dinchuk JE, Langenbach R, Trzaskos JM \& Dey SK 1997 Multiple female reproductive failures in cyclooxygenase 2-deficient mice. Cell 91 197-208.

Lin L, DeMartino GN \& Greene WC 1998 Cotranslational biogenesis of NF-kappaB p50 by the $26 \mathrm{~S}$ proteasome. Cell $92819-828$.

Lindstrom TM \& Bennett PR 2005 15-Deoxy-\{Delta\}12,14-Prostaglandin J2 inhibits IL-1\{beta\}-induced NF-\{kappa\}B in human amnion and myometrial cells: Mechanisms and implications. Journal of Clinical Endocrinology and Metabolism 90 3534-3543.

Loudon JA, Elliott CL, Hills F \& Bennett PR 2003 Progesterone represses interleukin-8 and cyclo-oxygenase-2 in human lower segment fibroblast cells and amnion epithelial cells. Biology of Reproduction $69331-337$.

Lye SJ, Mitchell J, Nashman N, Oldenhof A, Ou R, Shynlova O \& Langille L 2001 Role of mechanical signals in the onset of term and preterm labor. Frontiers in Hormone Research 27 165-178.

Malek S, Chen Y, Huxford T \& Ghosh G 2001 IkappaBbeta, but not IkappaBalpha, functions as a classical cytoplasmic inhibitor of NFkappaB dimers by masking both NF-kappaB nuclear localization sequences in resting cells. Journal of Biological Chemistry 276 45225-45235.

Marvin KW, Keelan JA, Eykholt RL, Sato TA \& Mitchell MD 2002 Use of cDNA arrays to generate differential expression profiles for inflammatory genes in human gestational membranes delivered at term and preterm. Molecular Human Reproduction 8 399-408.

Maymon E, Ghezzi F, Edwin SS, Mazor M, Yoon BH, Gomez R \& Romero R 1999 The tumor necrosis factor alpha and its soluble receptor profile in term and preterm parturition. American Journal of Obstetrics and Gynecology 181 1142-1148.

McCracken SA, Gallery E \& Morris JM 2004 Pregnancy-specific down-regulation of NF-kappa B expression in T cells in humans is essential for the maintenance of the cytokine profile required for pregnancy success. Journal of Immunology 172 4583-4591.

McLean M \& Smith R 2001 Corticotrophin-releasing hormone and human parturition. Reproduction 121 493-501.

McLean M, Bisits A, Davies J, Woods R, Lowry P \& Smith R 1995 A placental clock controlling the length of human pregnancy. Nature Medicine 1 460-463.

Mitchell BF \& Olson DM 2004 Prostaglandin endoperoxide H synthase inhibitors and other tocolytics in preterm labour. Prostaglandins Leukotrienes and Essential Fatty Acids 70 167-187.

Mohan AR, Sooranna SR, Johnson MR \& Bennett PR 2005 Mechanical stretch in human amnion cells activates both NF-kappaB and AP-1. Journal of the Society for Gynecologic Investigation 12 85A.

O'Connor S, Shumway SD, Amanna IJ, Hayes CE \& Miyamoto S 2004 Regulation of constitutive p50/c-Rel activity via proteasome inhibitor-resistant IkappaBalpha degradation in B cells. Molecular and Cellular Biology 24 4895-4908.

Olson DM 2003 The role of prostaglandins in the initiation of parturition. Best Practice and Research: Clinical Obstetrics and Gynaecology 17 717-730.

Opsjln SL, Wathen NC, Tingulstad S, Wiedswang G, Sundan A, Waage A \& Austgulen R 1993 Tumor necrosis factor, interleukin-1, and interleukin-6 in normal human pregnancy. American Journal of Obstetrics and Gynecology 169 397-404.

Osman I, Young A, Ledingham MA, Thomson AJ, Jordan F, Greer IA \& Norman JE 2003 Leukocyte density and pro-inflammatory cytokine expression in human fetal membranes, decidua, cervix and myometrium before and during labour at term. Molecular Human Reproduction 9 41-45.

Osmers RG, Blaser J, Kuhn W \& Tschesche H 1995 Interleukin-8 synthesis and the onset of labor. Obstetrics and Gynecology $\mathbf{8 6}$ $223-229$.

Ou CW, Orsino A \& Lye SJ 1997 Expression of connexin-43 and connexin-26 in the rat myometrium during pregnancy and labor is differentially regulated by mechanical and hormonal signals. Endocrinology 138 5398-5407.

Ray DA \& Garite TJ 1992 Prostaglandin E2 for induction of labor in patients with premature rupture of membranes at term. American Journal of Obstetrics and Gynecology 166 836-843.

Reznikov LL, Shames BD, Barton HA, Selzman CH, Fantuzzi G, Kim SH, Johnson SM \& Dinarello CA 2000 Interleukin-1 beta deficiency results in reduced NF-kappaB levels in pregnant mice. American Journal of Physiology: Regulatory, Integrative and Comparative Physiology 278 R263-R270.

Romero R, Mazor M \& Tartakovsky B 1991 Systemic administration of interleukin-1 induces preterm parturition in mice. American Journal of Obstetrics and Gynecology 165 969-971.

Romero R, Munoz H, Gomez R, Parra M, Polanco M, Valverde V, Hasbun J, Garrido J, Ghezzi F, Mazor M et al. 1996 Increase in prostaglandin bioavailability precedes the onset of human parturition. Prostaglandins Leukotrienes and Essential Fatty Acids $\mathbf{5 4}$ 187-191.

Romero R, Yoon BH, Kenney JS, Gomez R, Allison AC \& Sehgal PB 1993 Amniotic fluid interleukin-6 determinations are of diagnostic and prognostic value in preterm labor. American Journal of Reproductive Immunology 30 167-183.

Romero R, Mazor M, Brandt F, Sepulveda W, Avila C, Cotton DB \& Dinarello CA 1992 Interleukin-1 alpha and interleukin-1 beta in preterm and term human parturition. American Journal of Reproductive Immunology 27 117-123.

Romero R, Sibai BM, Sanchez-Ramos L, Valenzuela GJ, Veille JC, Tabor B, Perry KG, Varner M, Goodwin TM, Lane R. et al. 2000 An oxytocin receptor antagonist (atosiban) in the treatment of preterm labor: a randomized, double-blind, placebo-controlled trial with tocolytic rescue. American Journal of Obstetrics and Gynecology 182 1173-1183.

Romero R, Espinoza J, Chaiworapongsa T \& Kalache K 2002 Infection and prematurity and the role of preventive strategies. Seminars in Neonatology 7 259-274.

Rosen T, Krikun G, Ma Y, Wang EY, Lockwood CJ \& Guller S 1998 Chronic antagonism of nuclear factor-kappaB activity in cytotrophoblasts by dexamethasone: a potential mechanism for antiinflammatory action of glucocorticoids in human placenta. Journal of Clinical Endocrinology and Metabolism 83 3647-3652.

Rudolph D, Yeh WC, Wakeham A, Rudolph B, Nallainathan D, Potter J, Elia AJ \& Mak TW 2000 Severe liver degeneration and lack of NF-kappaB activation in NEMO/IKKgamma-deficient mice. Genes \& Development 14 854-862.

Schmitz T 2004 Is there a place for inhibition of cervical ripening in the management of preterm labour? European Journal of Obstetrics, Gynecology and Reproductive Biology 117 Suppl 1 S18-S20.

Schmitz ML, Mattioli I, Buss H \& Kracht M 2004 NF-kappaB: a multifaceted transcription factor regulated at several levels. Chembiochem: A European Journal of Chemical Biology 5 1348-1358. 
Sehringer B, Schafer WR, Wetzka B, Deppert WR, Brunner-Spahr R, Benedek E \& Zahradnik HP 2000 Formation of proinflammatory cytokines in human term myometrium is stimulated by lipopolysaccharide but not by corticotropin-releasing hormone. Journal of Clinical Endocrinology and Metabolism 85 4859-4865.

Sha WC, Liou HC, Tuomanen El \& Baltimore D 1995 Targeted disruption of the p50 subunit of NF-kappa B leads to multifocal defects in immune responses. Cell $80321-330$.

Slater DM, Berger LC, Newton R, Moore GE \& Bennett PR 1995 Expression of cyclooxygenase types 1 and 2 in human fetal membranes at term. American Journal of Obstetrics and Gynecology $17277-82$.

Slater D, Allport V \& Bennett P 1998 Changes in the expression of the type-2 but not the type- 1 cyclo-oxygenase enzyme in choriondecidua with the onset of labour. British Journal of Obstetrics and Gynaecology 105 745-748.

Soloff MS, Cook DL Jr., Jeng YJ \& Anderson GD 2004 In situ analysis of interleukin-1-induced transcription of cox-2 and il-8 in cultured human myometrial cells. Endocrinology 145 1248-1254.

Steinborn A, Kuhnert M \& Halberstadt E 1996 Immunmodulating cytokines induce term and preterm parturition. Journal of Perinatal Medicine 24 381-390.

Stevens MY, Challis JR \& Lye SJ 1998 Corticotropin-releasing hormone receptor subtype 1 is significantly up-regulated at the time of labor in the human myometrium. Journal of Clinical Endocrinology and Metabolism 83 4107-4115.

Stjernholm-Vladic Y, Stygar D, Mansson C, Masironi B, Akerberg S, Wang H, Ekman-Ordeberg G \& Sahlin L 2004 Factors involved in the inflammatory events of cervical ripening in humans. Reproductive Biology and Endocrinology 274.

Stygar D, Wang H, Vladic YS, Ekman G, Eriksson H \& Sahlin L 2002 Increased level of matrix metalloproteinases 2 and 9 in the ripening process of the human cervix. Biology of Reproduction 67 889-894.

Suyang H, Phillips R, Douglas I \& Ghosh S 1996 Role of unphosphorylated, newly synthesized I kappa B beta in persistent activation of NF-kappa B. Molecular and Cellular Biology $\mathbf{1 6}$ 5444-5449.

Tanaka M, Fuentes ME, Yamaguchi K, Durnin MH, Dalrymple SA, Hardy KL \& Goeddel DV 1999 Embryonic lethality, liver degeneration, and impaired NF-kappa B activation in IKK-beta-deficient mice. Immunity 10 421-429.

Tanaka Y, Narahara H, Takai N, Yoshimatsu J, Anai T \& Miyakawa I 1998 Interleukin-1beta and interleukin-8 in cervicovaginal fluid during pregnancy. American Journal of Obstetrics and Gynecology $179644-649$.

Terzidou V, Lee YS, Thornton S \& Bennett PR 2003 Identification of the response region on the oxytocin receptor (OTR) promoter which is important for the synergistic transactivation of OTR by C/EBPbeta and NF-kappaB transcription factors. Journal of the Society for Gynecologic Investigation 10 190A.

Terzidou V, Sooranna SR, Kim LU, Thornton S, Bennett PR \& Johnson MR 2005 Mechanical stretch up-regulates the human oxytocin receptor in primary human uterine myocytes. Journal of Clinical Endocrinology and Metabolism 90 237-246.

Thompson JE, Phillips RJ, Erdjument-Bromage H, Tempst P \& Ghosh S 1995 I kappa B-beta regulates the persistent response in a biphasic activation of NF-kappa B. Cell $80573-582$.

Traenckner EB, Pahl HL, Henkel T, Schmidt KN, Wilk S \& Baeuerle PA 1995 Phosphorylation of human I kappa B-alpha on serines 32 and 36 controls I kappa B-alpha proteolysis and NF-kappa B activation in response to diverse stimuli. EMBO J $142876-2883$.

Tsatas D, Baker MS \& Rice GE 1999 Differential expression of proteases in human gestational tissues before, during and after spontaneous-onset labour at term. Journal of Reproduction and Fertility $11643-49$.
Tsuboi K, Sugimoto Y, Iwane A, Yamamoto K, Yamamoto S \& Ichikawa A 2000 Uterine expression of prostaglandin $\mathrm{H} 2$ synthase in late pregnancy and during parturition in prostaglandin $\mathrm{F}$ receptordeficient mice. Endocrinology 141 315-324.

Vadillo-Ortega F \& Estrada-Gutierrez G 2005 Role of matrix metalloproteinases in preterm labour. BJOG: An International Journal of Obstetrics and Gynaecology 112 Suppl 1 19-22.

Varner MW \& Esplin MS 2005 Current understanding of genetic factors in preterm birth. BJOG: An International Journal of Obstetrics and Gynaecology 112 Suppl $128-31$.

Wang H \& Hirsch E 2003 Bacterially-induced preterm labor and regulation of prostaglandin-metabolizing enzyme expression in mice: the role of toll-like receptor 4. Biology of Reproduction 69 1957-1963.

Winkler M, Oberpichler A, Tschesche H, Ruck P, Fischer DC \& Rath W 1999 Collagenolysis in the lower uterine segment during parturition at term: correlations with stage of cervical dilatation and duration of labor. American Journal of Obstetrics and Gynecology 181 153-158.

Xiao G, Fong A \& Sun SC 2004 Induction of p100 processing by NF-kappaB-inducing kinase involves docking IkappaB kinase alpha (IKKalpha) to p100 and IKKalpha-mediated phosphorylation. Journal of Biological Chemistry 279 30099-30105.

Xu P, Alfaidy N \& Challis JR 2002 Expression of matrix metalloproteinase (MMP)-2 and MMP-9 in human placenta and fetal membranes in relation to preterm and term labor. Journal of Clinical Endocrinology and Metabolism 87 1353-1361.

Yamamoto $M$, Yamazaki S, Uematsu S, Sato $S$, Hemmi $H$, Hoshino K, Kaisho T, Kuwata $\mathrm{H}$, Takeuchi $\mathrm{O}$ \& Takeshige $\mathrm{K}$ et al. 2004 Regulation of Toll/IL-1-receptor-mediated gene expression by the inducible nuclear protein IkappaBzeta. Nature $\mathbf{4 3 0}$ $218-222$.

Yan X, Sun M \& Gibb W 2002a Localization of nuclear factor-kappa B (NF kappa B) and inhibitory factor-kappa B (I kappa B) in human fetal membranes and decidua at term and preterm delivery. Placenta 23 288-293.

Yan X, Wu Xiao C, Sun M, Tsang BK \& Gibb W $2002 b$ Nuclear factor kappa B activation and regulation of cyclooxygenase type-2 expression in human amnion mesenchymal cells by interleukin1 beta. Biology of Reproduction 66 1667-1671.

Yaron A, Hatzubai A, Davis $M$, Lavon I, Amit S, Manning AM, Andersen JS, Mann M, Mercurio F \& Ben-Neriah Y 1998 Identification of the receptor component of the IkappaBalpha-ubiquitin ligase. Nature 396 590-594.

Yoo HG, Shin BA, Park JS, Lee KH, Chay KO, Yang SY, Ahn BW \& Jung YD 2002 IL-1beta induces MMP-9 via reactive oxygen species and NF-kappaB in murine macrophage RAW 264.7 cells. Biochemical and Biophysical Research Communications 298 $251-256$.

Yoshida M, Korfhagen TR \& Whitsett JA 2001 Surfactant protein D regulates NF-kappa B and matrix metalloproteinase production in alveolar macrophages via oxidant-sensitive pathways. Journal of Immunology 166 7514-7519.

Young A, Thomson AJ, Ledingham M, Jordan F, Greer IA \& Norman JE 2002 Immunolocalization of proinflammatory cytokines in myometrium, cervix, and fetal membranes during human parturition at term. Biology of Reproduction 66 445-449.

Zhao J \& Karalis KP 2002 Regulation of nuclear factor-kappaB by corticotropin-releasing hormone in mouse thymocytes. Molecular Endocrinology 16 2561-2570.

Received 11 April 2005

First decision 16 June 2005

Revised manuscript received 29 July 2005

Accepted 30 August 2005 